\title{
Influence of Participatory Monitoring and Evaluation on Performance of Public Secondary Schools Projects in Mutomo Sub-County, Kenya.
}

\author{
Stellah Mueni Kathongo
}

Student at Kenyatta University \& DR Lucy Kamau Lecturer at Kenyatta University P.O BOX 4484400100 Nairobi, Kenya.

\begin{abstract}
In schools, participatory monitoring and evaluation is a tool for enhancing performance of projects and improving overall efficiency of project planning, management and implementation. PM\&E offers new way for involving the stakeholders in planning and implementation of projects in public schools environment. The purpose of the study was to establish influence of participatory monitoring and evaluation on performance of public schools projects in Mutomo Sub-County, Kenya. The population involves 33 public secondary schools which forms the target population of the study. Sampling design which was used in the study is non probability (purposeful sampling). The study collected data by use of questionnaires then descriptive analysis and inferential analysis was used for quantitative data. Data was presented by use of tables, percentages and frequencies, pie charts mean and standard deviations by statistical package (SPSS V17). The study established that stakeholders are not involved in the process of management of school projects. Moreover, established that institutional strengthening can be improved by open forums, meetings and seminars which should involve stakeholders air their views and negotiate their perspectives. The study concluded the following: institutional strengthening has influence on the performance since the stakeholders had little knowledge on participatory monitoring and evaluation and if the objectives will be achieved efforts can be made by the appointing authority to train the selected stakeholders .Negotiations perspectives of shareholders has influence on performance of public schools in the sub county, Public accountability still has influence on the performance of public secondary schools projects, Project planning has influence on performance of public school projects and lastly TSC policy has influence on the performance of public school projects. The study recommends that public secondary should involve the stakeholders in the process of projects management by creating meeting, forums and seminars that will allow them to air their views, needs and opinions which make them negotiate their perspectives and make critical decisions.
\end{abstract}

\section{Key Words: Participatory Monitory \& evaluation, Projects}

\subsection{Introduction}

Government and private business are actively involved in monitoring and evaluation of projects to ensure successful implementation for improved performance. A project is an intervention that consists of a set of planned, interrelated activities designed to achieve defined objectives within a given budget and a specified period of time (Filicetti, 2009). For projects to be implemented successfully as per set goals and objectives, the governments and stakeholders of education should get involved in the process of planning, monitoring and evaluation. Project success can be defined by the criteria of time, budget and deliverables and to add on this, Antill (2004) reported that a project can be successful if it is completed as schedule, within the budget, and if it achieves the expected set objectives and finally satisfy the desires of the stakeholders and the community

In previous years, the developing countries has been doing so poorly in management of projects giving inadequate performance in their institutions and organization due to several problems which can be managerial and organization (Lavagnon,2011). Most of these problems occur due to failures to involve the 
stakeholders and beneficiaries in the process of planning and implementation. For projects to be implemented successfully as per set goals and objectives, the governments and stakeholders should get involved in the process of planning, monitoring and evaluation.

Project management is the process of planning and controlling the activities of the projects to achieve the objectives and it aims at ensuring effective use of resources and delivery of the project objectives within the given time and within cost constraints. Mostly, project management gives results which are in better control and coordination with reduction of development time, low costs, and generally produce higher quality results. It forces the stakeholders to both consider what needs to be done to achieve project goals and work out how activities can be coordinated while considering possible risks and trying to mitigate them(Freeman et al, 2008).

Monitoring and evaluation (M\&E) is a good plan for managing projects because it ensures successful planning and implementation which leads to the success of the projects as per set goals and objectives and still encourages effective decision making for better performance of the projects. Research has shown that the performance of this monitored projects is inadequate because the performance bring disappointment to the beneficiaries and so the project in modern form which has grown currently make businesses, institutions and organization to understand the benefits of organizing work for projects in planning and implementing the projects effectively (Kutsch, 2008) by using participatory monitoring and evaluation plan to make the performance better than before.

World bank statistics show that the rate of project failure in Africa was over 50\% by year 2000 and all this was because monitoring and evaluation in the past, involved external experts who measured the performance of the project following the set indicators and objectives which lead to, uncompleted institutions projects. Incompletion of projects was due to mismanagement of funds, poor quality projects and projects which met short term objectives and still which do not satisfy the needs of the stakeholders. These problems call for great need to improve the performance of projects, by introducing PM\&E which involves the local stakeholders and the beneficiaries in planning and implementation of the projects by imposing local solutions to detected problems during implementation of projects, (Coupal, 2005).

Currently, PM\&E approach has more advantages than the old approach of $\mathrm{M} \& \mathrm{E}$ in the developing countries (Tana, Onyango, Ochola and Omolo, 2012). PM\&E differs from conventional approaches because it involves the stakeholders and the beneficiaries in the process of planning and implementing of the projects which lastly are completed in time and within the planned budget (World Bank,2010a).Moreover, (PM\&E) offers new ways of assessing and learning from new changes which affect perspectives and aspirations of stakeholders and beneficiaries(World Bank 2010b) which make the process of managing projects to be successful and give quality projects, completed within time and cost. PM\&E offers the institutions and organizations chances of improving the performance of the projects undertaken by both the Government and stakeholders of respective institutions.

Coupal, (2005) claims that the information assed from PM\&E provides stakeholders and project implementers with information which help them to know whether objectives have been met and how resources have been used and this help them to improve the performance by making critical decisions. PM\&E has an objective of institutional strengthening and capacity building of stakeholders which creates a feeling of ownership and belonging among the stakeholders. The forms of PM\&E helps the stakeholders undertake their activities better which increases the likelihood of successful implementation of the projects. Government and stakeholders of institutions around the globe are trying to satisfy the demands of improved reforms in school management and service delivery so that the vision 2030 (Education for All) can be achieved, (Yescombe, 2007). Government should encourage PM\&E by involving the stakeholders in the planning and implementation of the projects to help in improving the performance of projects in school management.

Previous in Kenya, the performance of projects in educational sector was inadequate, and so the government and stakeholders are concerned about the performance of FDSE and FPE. There is a policy for proving 
quality life to its citizen by year 2030 through provision of Education for All (EFA, Basic education Act 2013) and so the stakeholders should be foreseeing the implementation of the major projects at lower levels to improve and better the performance. To support Education For All (EFA), the government of Kenya (GOK) and the stakeholders of education in all levels are giving priority to planning, implementation and management of school projects to improve the welfare of its citizen and achieve vision 2030 (Education For All).

According to free day secondary education, the (GOK) is responsible coordinating, implementation and management of public school projects (Basic Education Act, 2013) and so the government agents and stakeholders of education at all levels should foresee the implementation of the project for the purpose of accountability. Government is putting a lot of efforts supporting free education (FPE and FDSE) by funding most of the public schools project to seal the gap between public investments needs and the available resources (Constitution, 2010 and Basic Education Act, 2013).

Key projects in public schools which government is foreseeing its implementation are: Free primary Education (FPE), Free Day Secondary Education (FDSE), ICT integration in education according to Basic Education Act, No. 14 of 2013. Building the main structures like dormitories, buying of school bus, and construction of the main building and installation of major facilities are other projects which are been undertaken by public schools and funded by the parents and previous the performance was not good because it gave disappointment results to the beneficiaries. This calls for the stakeholders to be involved in planning and implementation of such projects for transparency and accountability and be in a position to detect problems in advance for early correction.

There are many uncompleted projects in school environments in the country and there are very many criticisms in the way the principals are managing the school projects. The poor management of projects are due to inadequacy capacity building and lack of institutional building, failure to understand and negotiate stakeholder's perspectives, poor accountabilities and lack of transparency and finally lack of early planning .These points out a great need for strategic management of school projects which can be improved by using PM\&E plan in the process of implementing projects.

\subsection{Statement of the Problem}

Most of public secondary school projects in the developing country fail due to poor monitoring and evaluation and lack of the required skills during the project implementation. Ondieki and Matonda (2013) observed that there had been failure to engage parents, teachers, students and other local communities to air their views, needs, challenges and priorities as well as lacking capacity to organize, manage, monitor and evaluate projects using participatory monitoring and evaluation method. According to Igunnu et al. (2005), there are many faulty projects which are not managed and executed well which includes; uncompleted government buildings due to lack of funds, new schools without many structures, desks or teachers, incomplete dormitories, laboratories etc. These occurs because of lack of early planning and effective management, lack of public accountabilities and transparency, lack of institutional strengthening and capacity building of stakeholders and lastly lack of understanding and negotiating of stakeholders perspectives..

Most studies conducted research on Monitoring and evaluation and gave documents of findings and results, but very few which conducted research on PM\&E and how they empower stakeholders in planning and implementing projects (Miller \& Campbell, 2006). Therefore due lack of documentation evidence of done research on influence of PM\&E on performance of public secondary school projects in Mutomo sub county, Kenya, the researcher was propelled to undertake the research to establish the influence of participatory monitoring and evaluation on the performance of the public secondary schools projects in Mutomo Sub County, Kenya.

\subsection{General Objective}

The general objective of the study was to establish the influence of participatory monitoring and evaluation on performance of public secondary school projects in Mutomo Sub-County, Kenya. 


\subsubsection{Specific Objectives}

The research was guided by the following specific objectives:-

1. To assess the effect of institutional strengthening on the performance of public school projects in Mutomo sub county, Kenya

2. To establish the effect of negotiation perspectives on the performance of public school projects in Mutomo sub county, Kenya. s

3. To establish the effect of public accountability on the performance of public school projects in Mutomo sub county, Kenya.

4. To determine the effect of project planning on the performance of public schools in Mutomo sub county, Kenya.

5. To establish the effect of TSC policy on the performance of public school projects in Mutomo sub County, Kenya.

\subsection{Significance of Study}

The findings of the study helped the organization management, sponsors, government, policy makers and the community residents have insight on development and resource allocation and formulate policies and strategies on effective implementation of PM\&E in public secondary school projects and other projects was ensured that there was improvement in performances of public secondary schools in undertaking the projects activities with the aim of achieving the set objectives.

The treasury found that the findings of the study was important in evaluating the progress and performance of projects undertaken through public schools and be an eye opener to the concerned communities that they may feel motivated, sensitized and knowledgeable about their role to ensure the project implementation in public secondary schools is done successfully. It is further hoped that the findings of this study was important to other scholars and researchers as it gave them reference to their studies

\subsection{Scope of the Study}

The study covers all public secondary schools in Mutomo Sub County which are thirty three in number. Each school has its board of governors (principal), PTA representatives and teachers that filled questionnaires to give information about influence of participatory monitoring and evaluation on performance of their school projects. All the principals of the public schools, one teacher (H.O.D science) and PTA representatives (chairman) were selected from each school from the thirty three public secondary schools and filled the questionnaires.

\subsection{Theoretical Literature Reviews}

\subsubsection{Stakeholders Theory}

The theory deals with institutional management and business ethics which deals with moral and values which affect planning and management of institutions. It identifies stakeholders of a project and recommends the strategies which management gave due regard to the perspectives, demands and interests of those stakeholders. This tries to address the "Principle of Whom or What Really Counts" (Miles, Samanths 2012). Shareholder is any group or individual or organization who, directly or indirectly, stand to gain or loss from a given development activity or project.

According to Friedman 2006 perspective, all stakeholders have decision to make in implementation of projects and manage the interest's needs and view points of the stakeholders. Most projects consist of stakeholders and beneficiaries with different interests and demands, hence this makes public secondary school projects difficult to manage because of the need for negotiations perspectives that are involved (Yescombe, 2007). Bourne and Walker, 2005, research show that project success concerns the satisfaction of stakeholders and beneficiaries, early project planning and effective management of the projects, in addition of completion of projects within the budgeted cost, time and quality. The theory also described and recommended considerations of interest, expectations and demands of stakeholders by the management (Freeman and et, al, 2007). The main idea is that the project's success depends on how well the schools 
manages the relationship with the key groups: parents , students, teachers, board of management, communities, financiers and policy makers of education who can affect the realization of the project objectives (Freeman et al, 2007). Stakeholders disagreed on the measured results but understanding negotiation of stakeholder's perspectives may create opportunities to bring agreement on appropriate actions to be taken which will enhance performance of projects.

\subsubsection{Public participation theory}

Currently, the word public participation is a commonly used term in planning and management of projects and is well understood and defined differently by different researchers. FAO (2007) defines public participation as a process of equitable and active involvement of all stakeholders in the designing or formulation of developmental policies and strategies in the analysis, planning, implementation and monitoring and evaluation of developmental school activities.

According to Oduwo A.O (2014), public participation is a continuous process of negotiation and decisions making that occur at various stages with all stakeholders and influence the sharing and control of prioritization, resource allocation and access, and policy formulation and implementation of secondary school projects. Projects are expected to be more transparent when more people are involved and this can enhance better performance of the projects in institutions.

Pope et al, (2005), found that providing for public participation on development initiatives especially by the lowly disadvantaged minorities created a sense of belonging that resulted in embracing and owning of the initiatives and in public secondary schools can enhance the performance of projects. Brett, (2003) observes that many individuals and communities support public participation because it controls project activities and still he points out that public participation and involvement in decision making can succeed for certain projects depending on the circumstances. Public participation should be carried out in secondary school projects because it provides a level playing ground for individual interest, personal and social development.

According to Muhangi, (2007), public participation in secondary schools is a means of improving empowerment, a way of responding to society needs, ownership projects by the local people, and making projects cheaper by allowing mobilization of local resources. Public participation theory is believed to promote more equitable distribution of benefits that accrue from project activities and in connection with influence of PM\&E.

Oyuga, B.A (2011) argues that public participation empowers stakeholders (board of management, teachers, parents) so that they can continue to direct and support future changes and still empower them to demand services, develop a sense of owning the project and the sense of belonging to the projects and so it provides a good theoretical frame work and foundation on which this study can be based because it supports and argues for institutional strengthening and capacity building of stakeholders, Public accountability and transparency, understanding and negotiating stakeholders perspectives and lastly, early planning and management of projects which allows participants to gain a better understanding of any out coming problems and get immediate action.

\section{Empirical Literature Review}

\subsection{Participatory Monitoring and Evaluation}

$\mathrm{PM} \& \mathrm{E}$ is an important tool in management of projects because it improves service delivery, planning and allocation of resources and finally portraying the outcome of projects in a transparent manner (World Bank, 2004).According to Igunnu et al (2005), Projects in public secondary schools arise out of the desire to satisfy demands and needs of stakeholders and beneficiaries and try to achieve the objectives of vision 2030 (Education for All). Stakeholders may need to carry a project based on interest, demand and perspective of its stakeholders, or to improve an already existing project in the public schools. However, to implement the projects successfully there are influences of participatory monitoring and evaluation on improving performances of those projects in public which should be undertaken to improve the performances of the projects. 


\subsubsection{Institutional Strengthening}

$\mathrm{PM} \& \mathrm{E}$ is an educational experience for participants as well as local capacity building for performance of public school projects (Marc Holzer, Kathryn Klorby, 2008), and it improves the organization's capacity to execute selected activities to optimize performance of the projects. Institutional strengthening is defined as measures designed to improve the performance of projects in an organization or institution according to AWGA, (2011). From this definition it is evident that strengthening public secondary schools provides an opportunity to improve performance of development projects in secondary schools. Moreover it can mean making institutions to be effective and efficient in the process of identifying, planning, implementing, monitoring and the evaluation of secondary school development projects. AWGA note that capacity building of stakeholders and beneficiaries is a process of making stakeholders to determine their own values, priorities interest and act on their perspectives and decisions.

According to Jack and Samuel (2006), the term capacity building means the strategies taken by community to increase its people's knowledge, awareness and skills to solve the more underlying causes of poor project implementation and management. Capacity-building strategies which are planned to strengthen an institutional ability to provide quality, expected and effective services especially in educational sector.

Estrella and John, 1998, argue that with action oriented learning, participatory evaluation is an educational experience for participants as well as a means for local capacity building. PM\&E programs give clear guidelines for capacity building of stakeholders and how involve them, project clients, participants and partners in the $M \& E$ process. PM\&E produces important benefits including valid, timely and relevant information for management decision-making and project improvement within Educational institutions. PM\&E can leads to the following; improved capacity building which empowers the local people by putting them in charge; developing their skills of and showing them that their views count.

Participatory evaluation enables participants to acknowledge their abilities and weakness, their expectations and available resources and their vision and perspectives of project development results (Suarez-Herrera, 2009). Understanding the various factors that affect the condition and dynamics of their project, the basis for their success and failures, and the potential solution or alternatives actions (Estrella and John 1998), participants learn from experience, get abilities to evaluate their demands and needs, then analyze priorities and objectives for the desirable action to be taken.

For the performance of the school projects too much is expected from the government agencies and the stakeholders in terms of projects intervention delivery and implementation, and this calls for institutional strengthening and capacity building in public school projects. Through educational, learning process, stakeholder get knowledge and skills about their reality, clarify and then negotiate their perspective and desires to come to agreement about future action (Estrella et al. 2000).

In public school there are measures that the stakeholders should adapt in order to strengthen their project performances which can make the education sector achieve vision 2030, education for all (EFA). By assessing themselves, stakeholders may identify and get solutions to project related problems which help them strengthen their capacity making them active participants in project implementation. Self-assessment strengthens relationships between different stakeholders and this makes them increases the understanding of project planning, implementation and management.

\subsubsection{Negotiation Perspective}

PM\&E allows negotiations perspective which allows the stakeholders and beneficiaries to get better knowledge of their desires, interests, perspectives and roles. Different stakeholders perspectives negotiated allow the different interest stakeholders come to an agreement on what can do within their abilities what they need to monitor and evaluate. Stakeholders in the public secondary schools process have different claims, issues and concerns based upon their social values which influence by their realities. The inclusion of multiple stakeholders in the M\&E process is perceived by practitioners as a process which is building trust and confidence among stakeholders which improves the outcome of the project (Campilan, 2000). 
PM\&E inevitably requires negotiation to bring agreement among stakeholders planning, implementation process of the projects, who and how it was carried hence the need of a facilitator (Rossman, 2012). PM\&E strives to be an internal capacity building process that makes stakeholders to reflect on previous experience, review present realities, revisit objectives and state future plans by reviewing stakeholders' priorities and negotiating their demands, perspectives and interests (Estrella et al., 2000).

Yuan, Skibniewski, Li, and ZXheng (2010) argue that the expectations for efficient and effective public school projects stakeholders is to improve performance in management for the projects while considering stakeholders perspectives. Putting in mind all stakeholders' benefits and choosing the best performance objectives in the process of decision making can be important because of stakeholders' different preferences. Lemos and Bensusan, (2000), viewed stakeholder participation processes and concluded that it can help in choosing of the objectives and indicators which can enhance performance of projects and reduce biasness and corruption.

The negotiation process allowed the inclusion of multiple stakeholders in the evaluation and monitoring process which is perceived by practitioners as leading toward the creating trust and confidence among stakeholders which improve the performance of the projects (Campila,2000). PM\&E therefore needs capacity building which helps people learn about people's expectations and needs, and how different stake holders view the results, outcomes, and impacts of projects. (Gaventa and Blaunert, 2000) has a question of building a PM\&E process and how the involved stakeholder desires, needs and perspectives can be negotiated and then solution got, mostly to the local stakeholders who are powerless.

PM\&E process to have a culture that rewards innovation and openness is required and may need to be formed in management of projects (Bovens, 2005).In management of public school projects ,negotiation perspectives is paramount because different stakeholders has different desires, opinions and expectation of projects. To come up with the same perspectives the project managers and main stakeholders should come up with facilitated negotiation to be used in planning and management of project

\subsubsection{Public Accountability}

Public accountability pertains to the obligations of persons who have been entrusted with resources to be answerable for all the responsibilities that has been given to them, and should report to those who have given them the responsibilities. Accountability can be defined as giving and demanding of reasons for conduct from an individual or an institution. Kayhko (2011) argues that ensuring public accountability can be useful in setting high level strategic objectives and matters that are crucial to the public community, which spending of government and beneficiaries funds and the exercise of public responsibilities. In public accountability, one side is dealing with assigning of responsibilities and giving of resources while the other side will be dealing with accountability of the usage of the resources.

Bovens, M (2004) argues that awareness is increasing and the participation by projects stakeholders and beneficiaries in planning, implementation and management of projects is leading to improvement of performance hence success of project management. Objectives of public schools projects should be set and during times of planning with consultation of beneficiaries and project stakeholders together which should create transparency.

Ondieki, and Matonda,(2013) state that accountability of public schools projects is important to those who are involved in undertaking the planning, implementation and management. Like the government in funding free day secondary education and the stakeholders and beneficiaries should monitor and evaluation implementation of the projects to ensure that there is accountability and transparency in the process. This arrangement will allow stakeholders and the beneficially be in a position to articulate their needs, desires and expectations which makes them have various perspectives for negotiations for better decision making. Kaaria (2005) and Eldis, (2005), observation show that PM\&E provides a plan for decision making, building capacity and skills for stakeholders in assessing delivery of quality of service. Accountability and 
transparency is an indicator of PM\&E which is relevant to the study because in implementation of school projects there is need of accountability for the usage of allocated resources and transparency to prevent mismanagement of resources and corruption which improves the performance in public school projects.

\subsubsection{Project Planning}

Purpose of PM\&E can be to gain a timely and effective way in which information can be used for improving proper planning and implementation of public school projects (Meredith J. \&Mantel S. 2006). Project management generally consists of project planning, implementing and effective management. (Rosario,2000). As a management tool, PM\&E is used by different stakeholders (BOM, PTA, parents, teachers and students) to examine systematically on their activities and then plan for future goals and objectives. Stakeholder's participation in $\mathrm{M} \& \mathrm{E}$ can produce effective communication to facilitate project planning and coordination of various activities.

Larry, (2001), argues that planning for monitoring and evaluation must start at the time of project design, and they must be planned together with the objectives of the projects. According to Charles Norchi (2003) the objectives behind participatory planning, implementing and management in PM\&E is that in for the institutions to develop indicators well for measuring progress in public secondary schools projects they must be involved in formulation of the objectives of the project during the planning stage. This approach combines procedures, instructions and tools that stakeholders can use in the process of participating in the planning, implementation and management of projects

Campos and Coupal,(2000) claims that some functions of participation in evaluation is to provide all the stakeholders, project managers and government with information to check whether project objectives and plans have been met and whether the resources have been used effectively, in order to help improve project performance and make critical decision about project funding, improving project management, comparing planned and actual achievement in order to suggest improvement for future planning and implementation (Scott-Young C. \&Samson D. 2004). This planning of project implementation helps in detecting problems early then corrective measures are taken which public school projects improves its performance hence the sub county will achieve vision 2030 Education For All.

\subsubsection{TSC Policy}

Teachers' service commission of Kenya has its roles and duties which they have to play and the duties has big role in influencing the performance of secondary school projects. With regard to regulations of school resources, the TSC discharges this function by disciplinary enforcement to those who may be involved in mismanagement and embezzlement of these school funds. TSC is empowered to develop and apply a code of conduct governing the behavior of teachers (principals) in the process of allocating the resources in project of schools and the disciplinary action to be taken if the teachers go against the code of conduct.

In regard to deployment, TSC and ministry of Education have complementary functions of deploying County Education offices to ensure that each county has enough manpower and infrastructure to implement education policies in the counties. The deployment of county directors of education make the management of school programs to improve because they have a duty of monitoring FPE and FDSE ,facilitate auditing of the books of accounts of schools to enhance transparency and still they have a duty of advising on appointments of BOMs, School management committees and PTA members .All this influence the performance of public schools projects because the selected members fulfils the expected qualification to enable them manage projects effectively

\subsection{Research Gaps}

A close scrutiny of the literature review shows that very little has been done to establish the influence of participatory monitoring and evaluation on improving the performance of projects in public secondary schools and so this study will aim at establishing influence PM\&E on improving performance of projects in public secondary schools. The study bridges the gap of involvement of the stakeholders in projects implementation and so the researches poses the following questions How does institutional strengthening 
,negotiations perspectives ,public accountability, project planning and TSC policy affect the performance of public schools in Mutomo Sub County?

\subsection{Methodology}

The study used a descriptive research survey design which presents what is or what was, in a social system and it tries to give description behaviour, attitudes values and characteristics without changing them in any way.

The population involves 33 public secondary schools which forms the target population of the study. Sampling design which was used in the study is non probability (purposeful sampling). The study collected data by use of questionnaires then descriptive analysis and inferential analysis was used for quantitative data. Data was presented by use of tables, percentages and frequencies, pie charts mean and standard deviations by statistical package (SPSS V17)

\section{Data Analysis And Findings}

\subsection{Participatory Monitoring and Evaluation and performance}

The researcher wanted to find out whether the respondents accepted that PM\&E can

Influence performance of projects in the sub county.

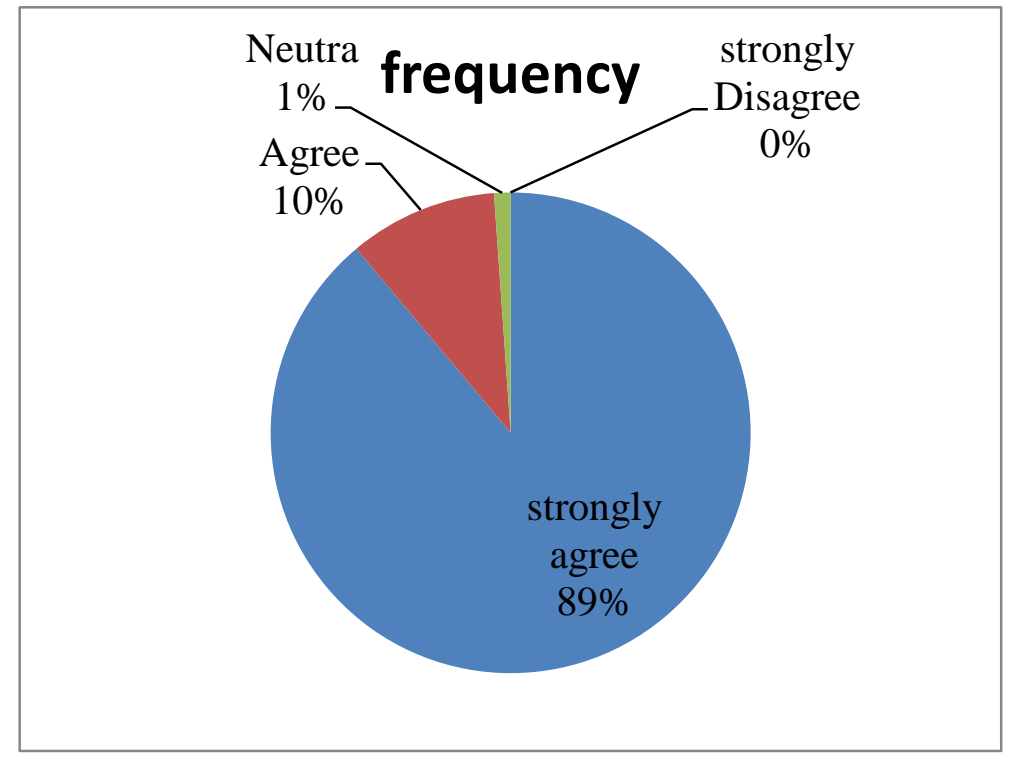

The study gave the following results which were presented above. Strongly agree was given by 80 respondents (89\%), Agree was given by 9 respondents (10\%), Neutral was given by only 0ne respondents $(1 \%)$ and none of the respondents $(0 \%)$ gave the response of strongly disagree. This showed that the stakeholders are in agreement that PM\&E can influence performance in secondary school projects. This study shows that most stakeholders are not involved in the management of projects in public secondary schools.

The study also established that PM\&E can influence performance by training stakeholders through workshops and seminars because from the statistics the stakeholders gave a mean of 4.3111, PM\&E leads to team building among stakeholders which gave a mean of 4.1111, PM\&E has been effective in improving conflict management among the stakeholders and it gave a mean of 4.3333, this is because the implementers of the schools and the community develops strategy to improve the relationship among themselves . PM\&E has been used to by the management team to monitor the progress of the projects and 
assess whether the projects are worthwhile and PM\&E has ensured that the stakeholders and beneficiaries airs their views through seminars and workshops which strengthen the institutions.

\subsubsection{Institutional Strengthening}

The researcher wanted to find out whether institutional strengthening had influence on performance of school projects. The results are as shown in the table below

\section{Table 4.7. Institutional strengthening}

\begin{tabular}{|l|l|l|}
\cline { 2 - 3 } \multicolumn{1}{l|}{} & MEAN & STD.DEV. \\
\hline $\begin{array}{l}\text { Training workshops and seminars influence } \\
\text { performances }\end{array}$ & 4.3111 & 0.66079 \\
\hline PM\&E leads to team building strategy & 4.1111 & 0.73719 \\
\hline $\begin{array}{l}\text { PM\&E improves conflict managements among } \\
\text { stakeholders }\end{array}$ & 4.3333 & 0.81670 \\
\hline $\begin{array}{l}\text { PM\&E enables the management team to } \\
\text { monitor progress of projects }\end{array}$ & 4.1222 & 0.86712 \\
\hline $\begin{array}{l}\text { Stakeholders participating in project } \\
\text { management can air their views }\end{array}$ & 4.0778 & 0.77779 \\
\hline $\begin{array}{l}\text { PM\&E is a tool of improving the performance } \\
\text { of projects. }\end{array}$ & 4.1667 & 0.68695 \\
\hline
\end{tabular}

From the study findings, the respondents indicated that to a great extent, institutional strengthening had ensured performance in public secondary schools projects.

The stakeholders had selected the appropriate indicators to show the views concerning the PM\&E which has given the following means: 4.3111, 4.1111, 4.3333, 4.1222, 4.0778, and 4.1667 respectively. In regard to the extent of institutional strengthening influence public secondary schools project Performance, the respondent's showed that involving all stakeholders with different views and opinions had strengthened the institution through workshops, conflict management and monitoring the progress of the projects.

\subsubsection{Negotiation Perspectives}

The study tried to establish the extent of agreement with various statements on the impact on Negotiations perspectives on influencing performance of secondary school projects in Mutomo Sub County as shown in the table 4.8 below.

\section{Table 4.8: Negotiation perspectives}

\begin{tabular}{|l|l|l|}
\hline & Mean & Standard Deviation \\
\hline $\begin{array}{l}\text { Negotiations of stake holders perspectives make } \\
\text { stakeholders give out their views }\end{array}$ & 4.3333 & 0.69941 \\
\hline $\begin{array}{l}\text { In your school, is negotiations of stakeholders } \\
\text { perspectives practiced during planning stage of } \\
\text { projects }\end{array}$ & 3.0667 & 0.99777 \\
\hline $\begin{array}{l}\text { Negotiations help the stakeholders know the ideals } \\
\text { they share. }\end{array}$ & 4.4889 & 0.95731 \\
\hline $\begin{array}{l}\text { PM\&E plan d forum develops forums which leads } \\
\text { negotiations of ideals to enhance performance }\end{array}$ & 4.7556 & 0.60175 \\
\hline
\end{tabular}

The respondents showed that negotiation perspectives made stakeholders to give out their views by giving a mean of 4.3333.It very clear from the stakeholder's responses that in public schools in the sub county, negotiation perspectives was not practiced during project management and this affected the performance of projects. The study has shown that negotiations perspectives are very minimal in public secondary schools. 
The study established that involving stakeholders in the process of school project management project can enhance performance on school projects.

The stakeholders have aided in the choosing the appropriate indicators on how PM\&E can enhance quality projects in schools. The negotiation perspectives can be done on open forums or meetings which are held to involve stakeholders in choosing the appropriate perspectives to come up with critical decisions in public school projects which have been difficult due to stakeholders' different preferences in Mutomo Sub County, Kenya. Negotiations perspectives can promote flexibility in making critical decisions, building trust of the stakeholders, even changing attitudes and behavior for them which enhance the performance of the projects.

\subsubsection{Public Accountabilities}

The study tried to establish the extent of agreement with various statements on the impact on public accountabilities on influencing the performance of secondary school projects in Mutomo Sub County. Involving public accountabilities in the process of project management had improved the performance of the projects. The responses were given as follows producing the given means and standard deviations. The results were given on the table 4.9 below

\section{Table 4.9 Public Accountabilities}

\begin{tabular}{|l|l|l|}
\hline & MEAN & $\begin{array}{l}\text { STANDARD } \\
\text { DEVIATIONS }\end{array}$ \\
\hline $\begin{array}{l}\text { Public Accountabilities enhance performance in } \\
\text { public schools }\end{array}$ & 4.4111 & 0.7731 \\
\hline $\begin{array}{l}\text { Public accountabilities has reduced mismanagement } \\
\text { of resources }\end{array}$ & 4.3889 & 0.67809 \\
\hline $\begin{array}{l}\text { Public accountabilities has lead to regular auditing } \\
\text { which improves performance of school projects }\end{array}$ & 4.2444 & 0.76492 \\
\hline $\begin{array}{l}\text { Public accountabilities will lead involvement of } \\
\text { stakeholders in implementation of school projects }\end{array}$ & 4.3556 & 0.82042 \\
\hline
\end{tabular}

From the table analysis, the respondents agreed that public accountabilities could enhance performance by creating transparency in the process of management of projects which gave a mean of 4.4111, The respondents still showed that Public accountabilities could be influenced by PM\&E to reduce mismanagement of resources because it gave a mean of 4.3889 .

Public accountabilities involved stakeholders in the process of implementation of school projects by leading to regular auditing of books of accounts which improved performance of school projects by enhancing transparency. This study has showed that public accountabilities in public secondary schools are very minimal that that's why there are faulty projects in these schools. The study has established that public accountabilities influence performances by, making the management team reduce mismanagement of the available resources, having regular auditing of books of accounts to see the inflows and outflows, and still by involving the stakeholders and the beneficiaries the in the process of management of projects

\subsubsection{Project Planning}

The study tries to establish the extent of agreement with various statements on the impact on project planning on influencing performance of secondary school projects in Mutomo Sub County as shown in the table 4.10 below. 


\begin{tabular}{|l|l|l|}
\hline & Mean & Standard Deviation \\
\hline $\begin{array}{l}\text { Project planning enhances performances in school } \\
\text { projects }\end{array}$ & 4.4889 & 0.61891 \\
\hline $\begin{array}{l}\text { Project planning leads to efficient utilization of } \\
\text { available resources }\end{array}$ & 4.6111 & 0.48877 \\
\hline $\begin{array}{l}\text { Project planning helps negotiations of stakeholders } \\
\text { which leads to formulation of main objectives hence } \\
\text { improved performance }\end{array}$ & 4.6000 & 0.61098 \\
\hline $\begin{array}{l}\text { Effective project planning leads to success of } \\
\text { projects in schools }\end{array}$ & 4.7778 & 0.41545 \\
\hline
\end{tabular}

The study found out that the project planning enhances performances of public school projects by helping negotiation perspectives of stakeholders which give formulation of main objectives. Project planning makes the management team to complete the projects within the given time, cost and use the available resources effectively. The study also established that project planning minimizes the stakeholder's conflicts because their perspectives are negotiated during this planning level which makes them come up with objectives which guide the implementations

\subsubsection{TSC Policy}

The researcher wanted to find out how the whether the external factors can affect the performance of projects. Three keys areas were considered: Usage of resources, deployment and regulations.

\begin{tabular}{|l|l|l|l|l|l|}
\hline & $\begin{array}{l}\text { Not at } \\
\text { all } \\
\%\end{array}$ & $\begin{array}{l}\text { Minimal } \\
\text { extent } \%\end{array}$ & $\begin{array}{l}\text { Moderate } \\
\text { extent } \\
\%\end{array}$ & $\begin{array}{l}\text { Great } \\
\text { extent \% }\end{array}$ & $\begin{array}{l}\text { Maximum } \\
\text { extent } \\
\%\end{array}$ \\
\hline $\begin{array}{l}\text { Supporting TSC policy assists in performance of } \\
\text { projects }\end{array}$ & 0 & 5.56 & 24.44 & 38.89 & 31.11 \\
\hline $\begin{array}{l}\text { Effective usage of available resources enhances } \\
\text { the performance of projects }\end{array}$ & 0 & 0 & 8.89 & 13.33 & 77.78 \\
\hline $\begin{array}{l}\text { Deployment of teachers and other stakeholders } \\
\text { can influence the performance of projects. }\end{array}$ & 0 & 11.11 & 22.22 & 27.78 & 38.89 \\
\hline $\begin{array}{l}\text { TSC regulations can influence the principals to } \\
\text { guide the other stakeholder on how to manage } \\
\text { projects which enhances quality projects } \\
\text { implementation }\end{array}$ & 0 & 33.33 & 38.89 & 16.67 & 11.11 \\
\hline
\end{tabular}

According to the respondents, TSC policy can affect the performance of the public secondary school projects by giving regulations which should be followed on management of the resources. Moreover the study has shown that effective's usage of available resources can affect the performance of the public school projects. The deployments of certain offices influence the performance of the projects. The study established that a TSC policy influences the performance of public secondary school projects by ensuring and guiding the stakeholders on rules and regulation pertaining mismanagement and embezzlement of school funds and resources. The study also established that deployment of county offices in each county influences the performances of the school projects because the officers concerned are involved in the process of monitoring and evaluation of all the programs undertaken in schools and still involved in advising on selection of BOM, school management committees and the PTA representatives.

\subsubsection{Performance of Public Secondary Schools}

The researcher wanted to find out the opinions of the stake holders towards influence of PM\&E on performance of public secondary schools projects. Scale used $1=$ greatly deteriorated $2=$ Deteriorated 3 $=$ Constant $4=$ Improved $5=$ greatly improved

The results in percentages was presented in a table 4.12 below 
Table 4.12 Performance of projects

\begin{tabular}{|l|l|l|l|l|l|}
\hline & $\begin{array}{l}\text { Greatly } \\
\text { deteriorated } \\
(\%)\end{array}$ & $\begin{array}{l}\text { Deteriorated } \\
(\%)\end{array}$ & $\begin{array}{l}\text { Constant } \\
(\%)\end{array}$ & $\begin{array}{l}\text { Improved } \\
(\%)\end{array}$ & $\begin{array}{l}\text { Greatly } \\
\text { improved } \\
(\%)\end{array}$ \\
\hline Stakeholders satisfaction & 0 & 0 & 0 & 13.33 & 86.67 \\
\hline Project quality & 0 & 0 & 0 & 11.11 & 88.89 \\
\hline Project completion within time and cost & 0 & 0 & 0 & 22.22 & 77.78 \\
\hline Improved economic status & 0 & 0 & 5.56 & 22.22 & 72.22 \\
\hline
\end{tabular}

The study showed that the respondents indicated that involving stakeholders in the process of project management can influence the stakeholders satisfaction which some said it could be improved (13.33\%) and other said greatly improved (86.67\%).Most of the respondents $(88.89 \%)$, indicated that PM\&E can produce quality projects which are completed within time and cost. The respondents $(72.22 \%)$ expressed their opinion of involvement of stakeholders in project management can improve economic status

\subsection{Conclusion}

The results from the study made the researcher to conclude that institutional strengthening has effect on the performance of public secondary schools in Mutomo Sub County. Therefore it is concluded that it is important to make sure that stakeholders are involved in the process of project management because they have different opinions to strengthen the institutions. All this has an advantage of meeting the set objectives.

The researcher still concluded that negotiation perspectives has effects on the performance of secondary school projects in Mutomo Sub County, Kenya which come up as a result of identifying seminars at the starting of the projects which will contribute to the success of the projects. The study also shows that negotiations perspectives enhance flexibility in the process of making critical decision which helps the stakeholders build trust and change attitudes and behavior and improves performance of project management.

From the findings, the researcher still concluded that public accountability has effect on the performance of public secondary school projects in Mutomo sub County. It is clear that PM\&E influences transparency on project management which makes the stakeholder have trust with the management of the projects. This has advantages because the stakeholder can plan, monitor, evaluate and control their resources and ensure effective management of projects.

The researcher still concluded that project planning has effects on the performance of secondary school project in Mutomo Sub County, Kenya which is because purpose of PM\&E can be to gain a timely and effective way in which information can be used for improving proper planning and implementation of public school projects. The researcher finally concludes TSC policy has effect on the performance of secondary school projects.

\section{Recommendations}

From the results and conclusions of this study, the researcher recommends that the public secondary schools should involve stakeholders in the process of project management who should be in front line to ensure that the set objectives are achieved; quality projects are got which satisfy their expectations. This is because PM\&E influences institutional strengthen which help the stakeholders learn more from meeting and forum which help to avoid conflicts and give them skills hence improving the interaction among the stakeholder.

The researcher recommends the schools should organize open forum and seminars which will give stakeholders to raise their views and opinions which will help in making critical decisions. This enables stakeholders to understand the views and values they share with other stakeholders. The researcher recommends the public secondary schools to create situation of encouraging public accountability because it creates trust in stakeholders .It is also good to put up that norms, procedures and incentives which will support transparency and accountability.

The researcher recommends that the government through TSC to organize training seminars which will make the stakeholders get skill and knowledge on monitoring and evaluation of projects. 


\section{Recommendation for Further Study}

Other studies should be done in other sectors to find out whether they can get the same findings. Further studies should also be done to find factors affecting participatory monitoring and evaluation on performance of projects.

The researcher suggests further study to be done on determinants of effective management on school projects and this research can help in carrying these other research.

\section{References}

[1]Abbot, J., Guijt, I. (1998). Changing views on change: participatory approaches to mosnitoring the environment. SARL Discussion Paper No. 2, July 1998. pp96. ISBN 1560-2192 London. IIED

[2] Arnstein, S.R. (1969). A ladder of citizen participation. Journal of the American Planning Association. 35 (4), 216-224

[3] AWGA (2011). Improving Public Sector Performance: Institutional Strengthening of The Alexandria General Water Authority, Egypt.

[4] Baer, B.N., D.C. Murphy \& D. Fisher. (1983). Factors affecting project success, Project Management Handbook.

[5] Bovens M, (2004), Public accountability in E. Ferlie;L.E Lynn, and C. Pollitt (ed.s),The Oxford Handbook of Public Management Oxford ,Oxford University Press.

[6] Brett,E. A (2003).Participation and accountability in development management Journal of Development studies, Vol. 40, No. 2.Rouutledge,part of the Taylor and Francis Group.

[7] Cleland, D.I. and King, W.R (2003). Systems analysis and project management. Mc Graw Hill, New York.

[8] Crawford, L. (2002). Project Performance Assessment. Masters in Project Management Course, 10th-15th June,

[9] Davies, R.J. (2000) Interviews with M\&E sections of Oxfam, SCF, ActionAid, Plan, and World Vision, in February. De Wit, A. (1988). Measurement of project success. International Journal of Project Management Vol. 6

[10] Freeman, R. Edward, and Daniel R. Gilbert, Jr. 2007. Corporate Strategy and the Search for Ethics (Englewood Cliffs, N.J.: Prentice-Hall).

[11] Gaventa, J. and J. Blauert. (2000). Learning to Change by Learning from Change. Oxford: Oxford University Press.

[12] Guijt, I. (2008) Participatory monitoring and impact assessment of sustainable agriculture initiatives. SARL Discussion Paper No. 1, July 1998. pp112. ISBN 1560-2192 London. IIED

[13] Kaaria, S.K and Njuki, J.M. 2005. Developing and supporting community-driven participatory monitoring and evaluation of marketing activities: CIAT, Kampala

[14] Käyhkö, E. (2011). Public Accountability to Citizens: From Performance Measures to Quality Thinking, Public Management Research Conference, Syracuse, NY

KESSP 2005-

2010. Delivering quality equitable education and training for all Kenyans.

[16] Meredith, J.R. \& Mantel, S.J (2006). Project Management: A managerial approach Monitoring and Evaluation NEWS web site, at www.mande.co.uk

[17] Mugenda, M. O and Mugenda, G.A (2003). Research Methods: Quantitative and Qualitative approaches. Laba - Graphics services, Nairobi.

[18] Ondieki, M. G. and Matonda, N. E. (2013). Influence Of Participatory Monitoring And Evaluation Approaches On The Practice Of Quality Assurance In Kenya Secondary Schools. Interdisciplinary, Journal of Contemporary Research in Business, 5 (3), 12-34

[19] Oyuga, B. A. (2011). Determinants of adoption of participatory monitoring and evaluation in management of public secondary schools in Kisumu East District, Kenya. Unpublished M.A project. University of Nairobi, Kenya

[20] Scott-Young, C. \& Samson, D. (2004). Project Success and Project Team Human Resource Management: Evidence 
[21] ESTRElla, M. and GAVENTA, J. (2000) Who Counts Reality? Participatory Monitoring and Evaluation: A Literature Review. IDS Working Paper 70. Brighton: Institute of Development Studies.

[22] Sphere (2000) SPHERE and Accountability - Monitoring and Evaluation. The Sphere Training Programme. Module 4 - One Day. Draft document.

[23] Tana P.O., Onyango, W. O. Ochola C. and Omolo, P. O. (2012). Socio-Cultural Participatory Monitoring and Evaluation Indicators Used in Adopting Improved Cassavas by Western Kenya Communities. Nairobi: Kenya Agricultural Research Institute.

[24] UNESCO. (2008). Education for All. Global Monitoring Report. Paris. UNESCO Publishing

[25] The World Bank (Editor) (2010): Participatory Monitoring and Evaluation, in Topics: Community Driven Development (b). Washington D.C.: The World Bank. URL [Accessed: 27.05.2010

[26] Oyuga, B. A. (2011). Determinants of adoption of participatory monitoring and evaluation in management of public secondary schools in Kisumu East District, Kenya. Unpublished M.A project. University of Nairobi, Kenya 